\title{
Retrograde Orotracheal Intubation with a Double-Lumen Tube
}

\author{
Jayme da Rocha Heck ${ }^{1}$, Frederico Krieger Martins ${ }^{2}$, Maria Teresa Ruiz Tsukazan ${ }^{2}$, Vivian Cristofoli ${ }^{2}$, \\ Maurício Pipkin ${ }^{3}$, Marner Lopes da Silveira ${ }^{3}$, Jayme de Oliveira Rios ${ }^{4}$, José Antônio Lopes de Figueiredo Pinto ${ }^{5}$
}

\begin{abstract}
Summary: Heck JR, Martins FK, Tsukazan MTR, Cristofoli V, Pipkin M, Silveira ML, Rios JO, Pinto JALF - Retrograde Orotracheal Intubation with a Double-Lumen Tube.

Background and objectives: Difficult airway management in thoracic surgeries is a peculiar subject due to the demands of monopulmonary ventilation with double-lumen tubes. Flexible bronchoscopy guidance is extremely important, but it is not always available. The objective of this report was to describe a case of retrograde selective orotracheal intubation in the absence of specific endoscopy equipment for the procedure.
\end{abstract}

Case report: This is a patient with a history of retosigmoidectomy, admitted for a right thoracotomy for a lung lesion. Preoperative anesthetic evaluation did not reveal any clinical and physical exam particularities. After anesthetic induction and ventilation with face mask, two attempts of orotracheal intubation under direct laryngoscopy were ineffective due to difficult visualization of the vocal folds (Cormack-Lehane grade III). Due to the unavailability of specific material for selective endoscopic intubation it was decided to use the retrograde technique using the double-lumen tube. The patient was extubated in the operating room shortly after the end of the surgery without complications secondary to the alternative technique.

Conclusions: Retrograde selective orotracheal intubation is a minimally invasive technique, low cost, safe, and extremely useful whenever flexible bronchoscopy is not available.

Keywords: Intubation, Intratracheal; Equipment Failure; Airway Management; Thoracotomy.

[Rev Bras Anestesiol 2011;61(4): 474-478] @Elsevier Editora Ltda.

\section{INTRODUCTION}

Difficult airway management is always a delicate situation for the medical team, since failure of planned procedures can cause prolonged hypoxia resulting in severe complications. In thoracic surgery selective orotracheal intubation for monopulmonary ventilation makes this issue even more complex because it demands greater ability of anesthesiologists to handle double-lumen tubes ${ }^{1}$. Flexible bronchoscopy is an important tool in most cases. However, whenever it is not available the use of alternative procedures is justified ${ }^{2}$.

The objective of this report was to describe a case in which retrograde orotracheal intubation was used, proven to be effective, inexpensive, and safe. It is considered an important alternative technique.

Received from the Serviço de Cirurgia Torácica of Hospital São Lucas. Pontifícia Universidade Católica do Rio Grande do Sul, PUCRS - Porto Alegre (RS) Brazil.

1. MD, Professor of the Disciplina de Anestesiologia, Chief of the Serviço de Anestesiologia of Hospital São Lucas, PUCRS

2. MD, Resident of the Serviço de Cirurgia Torácica of Hospital São Lucas, PUCRS

3. MD, Thoracic Surgeon of the Serviço de Cirurgia Torácica of Hospital São Lucas, PUCRS

4. MD, Associate Professor of the Disciplina de Cirurgia Torácica, PUCRS

5. MD, Professor of the Disciplina de Cirurgia Torácica, Chief of the Serviço de Cirurgia

Torácica of Hospital São Lucas, PUCRS

Submitted on November 28, 2010.

Approved on January 31, 2011.

Correspondence to:

Dr. Frederico Krieger Martins

Rua José Sanguinetti, 130

Ipanema

91760490 - Porto Alegre, RS, Brazil

E-mail: fredericokm@gmail.com

\section{CASE REPORT}

This is a 51 year-old male who underwent retosigmoidectomy for a malignant neoplasia two years ago who was admitted for surgical approach of an expansive lesion in the inferior lobe of the right lung, most likely metastatic. Pre-anesthetic assessment did not reveal any predictive factor for difficult intubation, neither the past medical history nor the physical exam.

Thiopental $\left(5 \mathrm{mg} \cdot \mathrm{kg}^{-1}\right)$ and cisatracurium $\left(0.20 \mathrm{mg} \cdot \mathrm{kg}^{-1}\right)$ were used for anesthetic induction. The patient was ventilated through a face mask with a mixture of oxygen and isoflurane for $3 \mathrm{mi}-$ nutes, an adequate time to achieve muscular relaxation for tracheal intubation. On direct laryngoscopy the epiglottis remained immobile and superimposed on the glottis hindering visualization of the vocal folds (Cormack-Lehane grade III). Thus, the patient was once more ventilated with a face mask. The second attempt to intubate him was also ineffective. It was then decided to use retrograde orotracheal intubation.

After adequate exposure and asepsis of the cervical region, the cricothyroid membrane was palpated. A mono-lumen central venous puncture kit was used in the tracheal puncture ${ }^{3}$. A set of needle and syringe with saline $2 \mathrm{~mL}$ were used for tracheal puncture. The presence of air bubbles was an indication that the trachea had been punctured. The needle was introduced on a cephalad direction and the metal guide-wire was introduced until it was visualized in the mouth. A pair of hemostatic clamps was used to catch the caudal extremity of the guide-wire close to the cervical region. The cephalad extremity was passed through the left side (bronchial) of a \#37 Carlens tube. Tension was applied on both extremities of the guide-wire and the tube was inserted until it stopped, indicating that the distal portion of the tube 


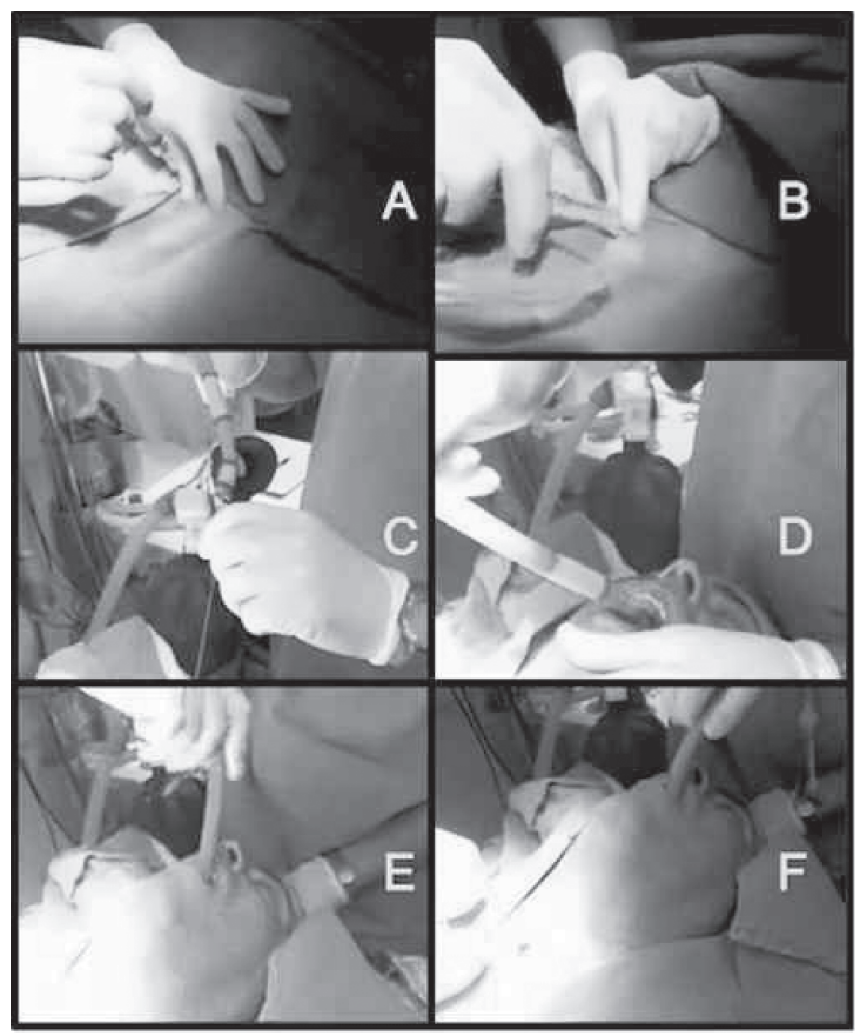

Figure 1 - Retrograde Selective Orotracheal Intubation.

(A) Tracheal puncture. (B) Introduction of the guide-wire. (C, D) Left Carlens tube advancing on the guide-wire until its trajectory is interrupted. (E) Tube being rotated $180^{\circ}$ counterclockwise followed by a (F) $90^{\circ}$ clockwise rotation.

had reached the site where the guide-wire was introduced into the airways. At this moment, the guide-wire was removed and the procedure continued as a selective intubation ${ }^{4}$. While advancing the tube it was rotated first at $180^{\circ}$ counterclockwise to pass the hook through the vocal folds followed by a $90^{\circ}$ clockwise rotation (Figure 1). Interruption of the progression suggested proper positioning of the hook in tracheal carina, which was confirmed both by pulmonary auscultation and capnography, especially if flexible bronchoscopy is not available.

Intercurrences were not observed during surgery. The patient was extubated in the operating room shortly after the end of the procedure. He did not develop complications secondary to the alternative intubation technique used, and he was discharge from hospital on the fourth postoperative day in good clinical conditions.

\section{DISCUSSION}

Ensuring a safe airway is one of the basic rules of anesthesiology. Most often, orotracheal intubation is performed without intercurrences; however, some times one can be faced with difficult airways. Thus, anesthesiologists must be familiar with alternative techniques of orotracheal intubation, since none of them has proven to be superior or effective in all cases. The main techni- ques used are direct laryngoscopy, retrograde, and guided by flexible bronchoscopy.

Since a consensus on the definition of difficult airway does not exist in literature, in order to unify the language to confront results with greater accuracy the American Society of Anesthesiologists has defined difficult airway as the clinical situation in which a properly trained anesthesiologist has difficulty with face mask ventilation and difficulty in performing tracheal intubation, or both ${ }^{5}$.

In thoracic surgical approaches, monopulmonary ventilation allows good exposure of the surgical field and less traumatism to the lung parenchyma during manipulation while protecting the dependent lung, justifying the use of selective double-lumen tubes 1,6 . Thoracotomies in which ipsilateral lung collapse is not achieved result in increased surgical duration and inadequate surgical field. Thus, a difficult airway in thoracic surgery is even more complex. In addition to obtaining a safe airway the anesthetic team has to perform, preferentially, selective intubation to contribute with the surgical team plans. These situations demand experience and adequate training.

In the present study we described a case in which selective retrograde orotracheal intubation was indicated. Despite the wide experience and well-established routines for flexible bronchoscopy for tracheal intubation, specific materials for endoscopic positioning of double-lumen tubes were not available. Thus, after two unsuccessful attempts in ideal conditions by a competent professional a decision for an alternative method was made.

Although very efficient and less invasive, flexible bronchoscopy has some hindrances. Selective endoscopic intubation requires costly materials: a double-lumen tube with a wide lumen made of polyvinyl and flexible bronchoscopy of small caliber. Note that the wear of fiberoptic fibers caused by the trajectory of the tube can damage the device and render it useless ${ }^{7,8}$. Although widespread, bronchoscopy still is an expensive technology inaccessible to several institutions and health care systems, especially in developing countries. A global survey on the accessibility of flexible bronchoscopy-guided orotracheal intubation on services of thoracic surgery does not exist in the literature. In the institution where the procedure was carried out, a flexible bronchoscope with a small enough caliber to go through a Carlens tube, a rigid tube with a small lumen, was not available and, therefore, it was not appropriate for endoscopy ${ }^{9}$.

The most common complication related to the retrograde technique is sore throat affecting $60 \%$ of patients. Complications of higher clinical importance are rare, and among them we could mention: soft tissue infection, hematoma, hemorrhage, subcutaneous emphysema, pneumomediastinum, and upper airways trauma ${ }^{4,10}$.

The importance of this report is based on the fact that the management of difficult airway is widely documented in literature; however, material on this situation in the presence of monopulmonary ventilation with double lumen tube especially when access to flexible bronchoscopy is not available is extremely rare.

Thus, retrograde access was more feasible. The procedure was performed without complications demonstrating to be a safe and low cost alternative technique of intubation. 
difficult airway: an updated report by the American Society of Anesthesiologists Task Force on Management of the Difficult Airway. Anesthesiology, 2003;98:1269-1277.

06. Heck JR - Princípios de Anestesia para Cirurgia Torácica, em: Pinto Filho DR, Cardoso PFG, Pinto JALF et al. - Manual de Cirurgia Torá-

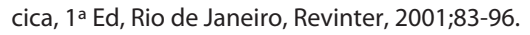

07. Mehta AC, Curtis PS, Scalzitti ML et al. - The high price of bronchoscopy. Maintenance and repair for the flexible fiberoptic bronchoscope. Chest, 1990;98:448-454

08. Rozman A, Duh S, Petrinec-Primozic M et al. - Flexible bronchoscope damage and repair costs in a bronchoscopy teaching unit. Respiration, 2009;77:325-330.

09. Pires AMD - Ventilação Monopulmonar em Cirurgia Torácica, em Cavalcanti IL, Cantinho FAF, Assad A - Medicina Perioperatória, 1a Ed, Rio de Janeiro, SAERJ, 2006;449-455.

10. Gill M, Madden MJ, Green SM - Retrograde endotracheal intubation: an investigation of indications, complications, and patient outcomes. Am J Emerg Med, 2005;23:123-126.

Resumen: Heck JR, Martins FK, Tsukazan MTR, Cristofoli V, Pipkin M, Silveira ML, Rios JO, Pinto JALF - Intubación Orotraqueal con Tubo de Doble Lumen por la vía Retrógrada.

Justificativa y objetivos: El manejo de la vía aérea difícil en cirugía torácica es un asunto peculiar, debido a las exigencias de la ventilación monopulmonar con el uso de tubos de doble lumen. El auxilio de la broncoscopia flexible es de enorme importancia, sin embargo no siempre está disponible. El objetivo de este relato, es describir un caso de intubación orotraqueal selectiva retrógrada en la ausencia de un equipo de endoscopia específico para el procedimiento.

Relato del Caso: Paciente con historial previo de retosigmoidectomía que fue ingresado para el abordaje quirúrgico de la lesión pulmonar por toracotomía derecha. La evaluación anestésica preoperatoria no revelaba particularidades ni en la historia clínica ni en el examen físico. Después de la inducción anestésica y ventilación con máscara facial, en la laringoscopia derecha dos intentos de intubación orotraqueal no tuvieron el efecto esperado debido a una difícil visualización de las cuerdas vocales (Cormack-Lehane grado III). En función de la indisponibilidad de un material específico para la intubación selectiva endoscópica, se optó por la técnica retrógrada utilizando un tubo de doble lumen. El paciente fue desentubado en quirófano enseguida que terminó la operación y no presentó complicaciones provenientes de la técnica alternativa.

Conclusiones: La intubación orotraqueal selectiva retrógrada fue una técnica alternativa mínimamente invasiva de bajo coste, segura e incluso extremadamente útil cuando no se cuenta con la ayuda de la broncoscopia flexible.

Descriptores: CIRUGÍA: Torácica; EQUIPO: Tubo traqueal; INTUBACIÓN TRAQUEAL. 